\title{
The Mediterranean and the Black Sea: Introduction
}

\author{
Nena Galanidou and Geoff Bailey
}

\begin{abstract}
The chapters in this section cover a very large area and two major marine basins, reflecting the somewhat scattered distribution of underwater finds and the patchy record of underwater research. Nevertheless, there are concentrations of finds with a detail and quality of evidence to match the best that has been found around the coastlines of north-west Europe. The evidence also includes types of sites and preservation of material items that have no equivalent elsewhere, including submerged village settlements with timber-built platforms and dwelling structures, and settlements with remains of stone-built dwellings, burials, street plans, water wells and other features. Most of these sites are Neolithic or Bronze Age in date, but there are also earlier finds extending back as far as the Middle Palaeolithic. The types of sites represented also include underwater caves containing deposits with palaeontological and archaeo-
\end{abstract}

N. Galanidou $(\bowtie)$

Department of History and Archaeology,

University of Crete, Rethymno, Greece

e-mail: galanidou@uoc.gr

G. Bailey

Department of Archaeology, University of York, York, UK

College of Humanities, Arts and Social Sciences, Flinders University, Adelaide, SA, Australia

e-mail: geoff.bailey@york.ac.uk logical remains. Sea-level change presents a complex story in this region, especially around the coastlines of southern Italy and the Aegean and the Black Sea, and intensive research has focussed on this issue, with implications for the changing palaeogeography of coastlines and islands and the possibility of sea crossings and maritime connections. This introductory overview brings together results from the chapters in this section under four main themes: underwater caves, sea crossings, mapping of submerged landscapes and predictive modelling of underwater site locations and underwater settlements. New and active research is under way in some regions, including the extension of mapping and site survey to more deeply submerged areas of the continental shelf. These results suggest very considerable potential for new discoveries and the need to extend underwater research to other coastal states that have so far made little or no contribution to the prehistoric archaeology of submerged landscapes.

\section{Keywords}

Underwater caves · Palaeolithic $\cdot$ Neolithic . Bronze Age $\cdot$ Submerged landscapes . Predictive modelling 


\subsection{Introduction}

Of all the regional sections, this one covers the largest area and at the same time has the smallest number of underwater finds, with 138 recorded finds (Appendix I). Known sites are relatively few or exist as isolated discoveries, and some countries have yet to yield any finds at all, although those included here, namely, Malta (Gambin, Chap. 17, this volume) and Ukraine (Kadurin et al., Chap. 21, this volume), clearly have promising conditions for new discoveries. As indicated in the Introduction (Bailey et al., Chap. 1, this volume), this paucity of finds reflects in a general way both differences in coastal geology and geomorphology and different intellectual interests and histories of underwater investigation. Nevertheless, the known underwater finds extend from as early as the Middle Palaeolithic in Croatia (Radić Rossi et al., Chap. 18, this volume) and Israel (Galili et al., Chap. 23, this volume) to the Bronze Age or later, especially in Italy (Castagnino Berlinghieri et al., Chap. 16, this volume), Croatia (Radić Rossi et al., Chap. 18, this volume), Greece (Galanidou et al., Chap. 19, this volume) and Bulgaria (Peev et al., Chap. 20, this volume). They represent a variety of site types including cave deposits, palaeontological finds, votive deposits and village settlements with details of settlement layout and features such as dwelling structures of timber and stone, pits and burials. In two areas, Bulgaria (Peev et al., Chap. 20, this volume) and Israel (Galili et al., Chap. 23, this volume), the concentration of underwater sites along limited stretches of coastline and the range of finds and quality of preservation are comparable to the underwater settlements of the western Baltic in Denmark and Germany (Bailey et al., Chap. 3, this volume; Jöns et al., Chap. 5, this volume).

It is broadly true to say that investigation of submerged Stone Age landscapes throughout these marine basins has been overshadowed by an interest in shipwrecks and submerged remains of shoreline infrastructure such as harbours, fish tanks, ship sheds and settlements relating to the Bronze Age, Iron Age and classical antiquity. In part, this reflects the fact that the Mediterranean and the Black Sea already from an early period were coming under the influence of maritime exploration, trade and colonisation associated with the development and expansion of Neolithic and Bronze Age societies at a time when Stone Age societies in NW Europe were hunting and fishing along the now-submerged coastlines of the North Sea and the Baltic or expanding into the newly deglaciated regions further north. It also reflects the fact that some coastal regions, notably in southern Italy and Greece, have continued to sink after stabilisation of eustatic sea level because of their tectonic history, with the partial or total submergence of coastal settlements and harbours of later periods.

Another disincentive to underwater exploration for submerged Stone Age sites and landscapes noted by Arias (Chap. 13, this volume) is the relative narrowness of the continental shelf along many sections of the Mediterranean coastline- $\leq 5-10 \mathrm{~km}$. Here, the amount of land exposed at lowest sea level was relatively small, and its periodic exposure and inundation by changes in sea level had less dramatic effects than on shallower continental shelves elsewhere. Narrow shelves also encourage the view, not necessarily justified, that sites such as caves situated on the present-day coast are close enough to provide a sufficient window into the use of the submerged landscape and its palaeoshorelines without the need for underwater exploration. Because of the geology and topography of the Mediterranean coast, coastal caves of this type are common. They include some of the most important and best-known Palaeolithic sequences in the Mediterranean such as Gorham's Cave in Gibraltar (Arias, Chap. 13, this volume), the Monte Circeo caves of Italy (Castagnino Berlinghieri et al., Chap. 16, this volume), Crvena Stijena in Montenegro on the east Adriatic coast (Whallon 2018), the caves of the Mani Peninsula and Franchthi Cave in Greece (Galanidou et al., Chap. 19, this volume), Ksar Akil in Lebanon (Tixier 1974), the Mount Carmel Caves in Israel (Galili et al., Chap. 23, this volume) and the Haua Fteah in Cyrenaica, Libya (McBurney 1967; Barker et al. 2007). Similar examples are present on Atlantic coastlines, notably in northern Spain 
(Arias, Chap. 13, this volume) and on the island of Jersey (Bailey et al., Chap. 10, this volume).

These sites, not surprisingly given their deep stratified sequences and abundant remains, have attracted considerable attention and resources in their investigation and play an important role in providing insights into the use of the adjacent territory that is now submerged. However, as the chapters in this section make clear, these on-land caves are part of a continuum that extends to submerged caves offshore and below present sea level. Moreover, on-land caves on the modern coastline need to be complemented by underwater investigation of the adjacent submerged landscape, the ways in which that landscape and its resources were modified by sea-level change, and how these changes in their turn affected the site catchment of the caves located on the modern coast, their varying attractiveness for human occupation at different periods and the nature of the food remains and artefacts deposited within them. Moreover, submerged cave sites, even those quite close to the present coastline, may give evidence of human activities not represented in the deposits of caves on land.

Notwithstanding these disincentives to underwater exploration, it is worth noting that the preconditions that have encouraged underwater investigations in north-west Europe, namely, exposure of artefacts and other features in the intertidal or shallow water zone, are clearly present on some Mediterranean and Black Sea coastlines. These examples include stone tools eroded out from underwater deposits or visible in pedestrian surveys along the modern shoreline (Arias, Chap. 13, this volume; Radić Rossi et al., Chap. 18, this volume); soft sediments and peats in shallow bays where culture layers and artefacts are often brought to light by commercial activities such as dredging, notably in France, Croatia and Bulgaria (Billard et al., Chap. 12, this volume; Radić Rossi et al., Chap. 18, this volume; Peev et al., Chap. 20, this volume); and remains of stone structures easily visible in shallow water in Italy, Greece and Israel (Castagnino Berlinghieri et al., Chap. 16, this volume; Galanidou et al., Chap. 19, this volume; Galili et al., Chap. 23, this volume). There is also a strong scientific tradition of investigating sealevel change, a theme increasingly focussed on the human impact of such changes (Benjamin et al. 2017).

In at least three cases, underwater investigation motivated primarily by the search for shipwrecks has resulted in the discovery of important underlying prehistoric deposits with cultural material, notably at Cala Tramontana on the island of Pantelleria (Abelli et al. 2016, p. 97; Castagnino Berlinghieri et al., Chap. 16, this volume), Zambratija in Croatia (Benjamin et al., 2011, p. 194; Radić Rossi et al., Chap. 18, this volume) and Urdoviza on the Bulgarian coast (Angelova and Draganov 2003, p. 12; Peev et al., Chap. 20, this volume).

Closer examination of the Mediterranean and Black Sea underwater sites reveals some similarities with the more abundant material in the other marine basins, as well as contrasts. We highlight four themes: underwater caves, sea crossings, mapping and predictive modelling and underwater settlements.

\subsection{Underwater Caves}

Caves with an opening at sea level and with preservation of deposits with evidence of human occupation when sea level was lower than present have been recognised as a potential window into the submerged landscape since Blanc's (1940) observations at Grotta Palinuro in Italy, where he observed cemented deposits containing bone fragments attached to the cave walls extending below modern sea level. Since that time, thousands of underwater caves have been explored by divers in the karstic geology around the northern coastline of the Mediterranean. However, reports of underwater deposits are rare, and those with archaeological remains are even rarer. Flemming and Antonioli (2017) offer a comprehensive overview and suggest that the rarity of archaeological remains may be due to a variety of causes. These include removal of deposits by marine erosion; the preservation of deposits by cementation or beneath a protective overburden of marine sediments, rockfalls and biogenic accretions, posing 
major logistical obstacles to access and excavation; and perhaps also the lack of archaeological expertise and an eye for anthropogenic indicators amongst the divers who have conducted underwater exploration. As Billard et al. (Chap. 7, this volume) note in relation to the coastal karst of the French Mediterranean, most of these underwater investigations have been carried out for speleological or hydrological purposes rather than archaeological ones.

Caves that are empty of deposits or lacking archaeological evidence of use are common in surveys on land. Here, caves with archaeological deposits are usually shallow openings with specific conditions of size, aspect, elevation above the valley floor, location with respect to topography and animal movements, and geomorphological conditions conducive to the accumulation and retention of sediments. These sites are usually only a small percentage of the total available in the limestone regions of Europe. So it is not surprising that many underwater caves lack human evidence. The critical question is whether cave deposits with remains of terrestrial deposits and human activities could have survived the destructive processes of marine inundation.

Examples from the following chapters include both caves with openings at or close to modern sea level, which cannot be accessed today except from the sea, and also fully submerged caves. Examples of the former are Cova del Gegant in Spain, with Mousterian artefacts and Neanderthal remains (Arias, Chap. 13, this volume); Grotta Verde and Grotta dei Cervi on the island of Sardinia, Italy, the former with Neolithic burials and the latter a palaeontological deposit (Castagnino Berlinghieri et al., Chap. 16, this volume); the Vamos Cave on Crete with palaeontological deposits but no evidence of human activity; and the Kalamakia Cave on the Mani Peninsula of the Greek mainland with Middle Palaeolithic occupations (Galanidou et al., Chap. 19 , this volume).

Fully submerged caves include an important group of sites in the Couronne and Calanques massifs of the French Mediterranean coast, some with breccias containing animal bones and stone artefacts, and the exceptional case of the Cosquer
Cave (Billard et al., Chap. 12, this volume). Here, an inner chamber contains painted wall art and remains of hearths dated to the LGM (Last Glacial Maximum). This inner chamber is above present sea level but can only be reached along a narrow upward sloping corridor $150 \mathrm{~m}$ from a cave mouth that is now $37 \mathrm{~m}$ below present sea level. Also in this category are submerged caves off the island of Corfu at a depth of $40 \mathrm{~m}$, with stone artefacts on the seabed nearby that may have been eroded from deposits within the caves and off Agios Petros in the northern Sporades (Galanidou et al., Chap. 19, this volume).

As far as preservation is concerned, deposits have remained in place either because they are high enough to be clear of wave action even at highest sea level, with evidence that earlier and deeper deposits have been washed out during marine transgression, or because of cementation that has helped to resist wave attack. The presence of faunal remains in submerged cave deposits on Sardinia and Crete shows that cave deposits can be preserved after submergence. However, artefacts are absent in both cases either because the caves were not suitable for human occupation or perhaps because humans were not present on these islands during the Pleistocene, a point that we return to below.

All these indicators suggest considerable further potential for the archaeological investigation of underwater caves, especially those where local conditions may have resulted in the preservation of deposits. Landward-facing caves protected from the full force of waves are one possibility, and it is notable that the Vamos cave in Crete falls into this category. Preservation of terrestrial deposits protected beneath a later overburden of rockfalls and marine sediments offers another possibility. But the logistical problems of investigating these deposits should not be underestimated. Preliminary excavation into the uppermost deposits of a cave in a landward-facing cliff on Vladi's Reef, and at a depth of $19 \mathrm{~m}$, just offshore of the Gibraltar coastline, is reported by Arias et al. (Chap. 13, this volume). However, further work has been deferred because of the resources and engineering solutions needed to remove rockfalls that block the cave entrance. 


\subsection{Sea Crossings}

The Mediterranean has four large islands that have always been detached from their adjacent mainland throughout the Pleistocene sea-level cycle: Cyprus (Ammerman, Chap. 22, this volume), Crete (Galanidou et al., Chap. 19, this volume), Sardinia and Corsica-a single land mass at lower sea levels - and Sicily, though the latter was briefly connected to the Italian mainland at the LGM (Castagnino Berlinghieri et al., Chap. 16 , this volume). They are well known for their unusual mammalian fauna of now-extinct animals, which show the evolution in isolation of species that have no mainland analogues, most famously the pygmy elephant and pygmy hippo (Davis 1967, Athanassiou et al. 2015 and references therein). There is also a scattering of smaller islands, notably in the Aegean, some of which, such as the Melos group, coalesced to form a larger land mass when sea levels were lower.

Although it was once assumed that these islands were not colonised until the expansion of Neolithic farmers and that the extinction of the endemic fauna was the result of that human invasion, it is now widely accepted that sea crossings to some of the islands in the Aegean and eastern Mediterranean were undertaken by Epipalaeolithic or Mesolithic seafarers as early as 13,000 years ago, well before the arrival of Neolithic farmers (Laskaris et al. 2011; Galanidou et al., Chap. 19, this volume; Ammerman, Chap. 22 , this volume). The further question arises as to whether these large islands, apparently with sufficient resources to sustain resident human populations of hunter-gatherers, were reached at a much earlier date in the Pleistocene, with all that this implies about the seafaring capabilities of Palaeolithic populations (Galanidou 2009, 2014). Yet it is also important to emphasise that sea crossings include both organised voyages and serendipitous crossings or accidental drifting (Dennell et al. 2014); in the latter case, the archaeological imprint would be minimal if any (Papoulia 2016, p. 43).

The clear evidence in Australasia that short sea crossings took place as early as 800,000 years ago, and in a sustained fashion over longer distances from at least as early as 60,000 years ago (Hiscock 2008; Clarkson et al. 2017), certainly encourages the search for similar evidence in the Mediterranean. Indeed, repeated claims have been made for a Palaeolithic presence on the large Mediterranean islands, most recently the finds from south-western Crete (Runnels 2014 and references therein). The early Palaeolithic status of these finds has been questioned and remains contested because of doubts about the human origin of the material in question or about its stratigraphic provenance and dating (Broodbank 2014; Galanidou 2014; PhocaCosmetatou and Rabett 2014).

The investigation of submerged landscapes discussed in the following chapters does not at present offer any decisive resolution of these uncertainties, but the focus on sea-level change and palaeoshoreline reconstruction certainly raises some relevant questions and intriguing clues.

The first and most important question is the changing palaeogeography of island connections with changes in sea level. Perhaps the best evidence of islands that were never connected to their adjacent mainland but were nevertheless occupied, or at any rate visited, during the Palaeolithic comes from the Ionian coast of Greece, where lithic assemblages with Middle and Upper Palaeolithic affinities have been found on the offshore islands of Zakynthos, Kephallinia and Atokos (Ferentinos et al. 2012; Galanidou 2018; Galanidou et al., Chap. 19, this volume). The sea crossings required would always have been quite short-less than 7-5 km (Papoulia 2017 , p. 82; Galanidou et al. in prep), and it is possible that the limited number of artefacts attributed to the Palaeolithic are nothing more than the result of serendipitous crossings to these Ionian islands (Galanidou 2018; Papoulia 2018).

In Italy, there is the intriguing underwater find of Cala Tramontana on the island of Pantelleria (Castagnino Berlinghieri et al., Chap. 16, this volume). The island was never closer than $20 \mathrm{~km}$ to the nearest mainland, even at the lowest sea level, so that sea crossings over a significant distance would always have been required to reach 
it. It was important during the Neolithic period as a major source of obsidian, but Cala Tramontana appears to be of earlier date. The deposits with the artefacts are at 18-21 m below present sea level. They are not directly dated but fall within the period 9600 to $7700 \mathrm{cal} \mathrm{BP}$ according to the local sea-level curve, and their expedient manufacture is consistent with short visits to the island. Whether the visits were specifically to collect obsidian and take it away for use elsewhere is not clear, but the evidence raises the intriguing question of whether obsidian artefacts sourced to Pantelleria are present in pre-Neolithic archaeological deposits elsewhere. In any case, the Cala Tramontana find is relatively late in date and casts no light on the possibility of earlier sea crossings.

In Italy, detailed studies of sea-level change and palaeogeographic reconstructions offer additional insights (Castagnino Berlinghieri et al., Chap. 16, this volume). Sardinia was separated from the Italian mainland even at lowest sea level during the LGM by a sea crossing of $12 \mathrm{~km}$ and has no certain evidence of human presence before the Mesolithic period at $8700 \mathrm{cal}$ BP. Stone tools of earlier data have been claimed but not substantiated. The island of Pianosa in the Tuscan Sea was connected to the mainland during the LGM, and the presence of Upper Palaeolithic industries shows human entry and occupation in that period. Subsequently, with sea-level rise, the island was cut off by a sea channel $10 \mathrm{~km}$ wide and was apparently abandoned, only to be reoccupied after a long interval during the Neolithic period.

Sicily is especially interesting because the Strait of Messina between Sicily and the Italian mainland is only $4 \mathrm{~km}$ wide, at most, but is notorious for its treacherous currents. Detailed modelling of changes in channel geometry and tidal velocities in response to sea-level change shows that these treacherous conditions would have persisted at lower sea levels but that a land connection would have existed for about 10,000 years during the LGM. It is during this period that abundant evidence of human occupation in the form of Upper Palaeolithic industries appears in Sicily along with the entry of a modern fauna including red deer and wild ass (Castagnino Berlinghieri et al., Chap. 16, this volume).

One interesting consequence of the LGM land connection between mainland Italy and Sicily is that low sea levels at this time would have opened up a land corridor extending further south from Sicily to incorporate Malta in an elongated peninsula, representing an attractive thoroughfare for the dispersal of mammals and a cul-de-sac that would have facilitated their trapping by human hunters. Gambin (Chap. 17, this volume) notes that there are pollen indicators suggesting the presence of agriculture on Malta at a date when sea levels were lower than present and before the earliest dated archaeological sites on the modern coast. Extensive mapping of the submerged landscape has also identified features that might hold promise for archaeological exploration in search of earlier sites, and that possibility represents a high priority for future research.

The implication of the above examples from western Greece and Italy is that short sea crossings, of the order of $5 \mathrm{~km}$ or less, especially in sheltered waters, were certainly achievable at least as early as the Middle Palaeolithic but that longer distances in the $5-10 \mathrm{~km}$ range or more were marginal for Palaeolithic populations and that unequivocal evidence for such crossings is not apparent until the very end of the Pleistocene or the early to mid-Holocene period (Epipalaeolithic, Mesolithic and Neolithic). Similar considerations apply to Crete where mapping of palaeogeographic changes taking account of eustatic and tectonic effects indicates that Crete could have been reached periodically during Pleistocene low sea-level stands by islandhopping across relatively narrow sea channels from mainland Greece or Turkey (Sakellariou and Galanidou 2016, 2017; Galanidou et al., Chap. 19, this volume).

However, it would be unwise to overgeneralise about Palaeolithic seafaring capabilities from these limited examples. Here, as in all other aspects of underwater research, local factors are likely to be of paramount importance and highly variable. The Italian examples refer to islands that were either too small or too distant to encourage regular visitation or were isolated by short 
and narrow straits where funnelling of sea currents would naturally create more dangerous conditions for sea crossings. Equally, the presence of a Pleistocene fauna on these islands, including animals with good swimming abilities such as deer and mammoth, suggests that sea channels were periodically narrow enough to be swum across; and if these animals could make the crossing, then we should allow the same possibility to humans. At any rate, the current evidence offers little encouragement for the idea of organised sea crossings over long distances from the North African coastline to southern Europe during the Pleistocene. These would have required sea journeys of at least $50 \mathrm{~km}$, with the exception of the $11-\mathrm{km}$-wide Strait of Gibraltar, but even in the latter case, with substantial Palaeolithic caves on both sides of the Strait, decisive evidence of Palaeolithic sea crossings has yet to be identified (Bailey et al. 2008). The only other comment relevant to this discussion is that since the period of greatest interest is one when sea levels were substantially lower than present, there is a strong likelihood that coastal sites with decisive archaeological evidence are now submerged, and this in its turn should reinforce the incentive for underwater exploration.

\subsection{Mapping and Predictive Modelling}

Key to the above discussion of sea crossings is the mapping of palaeoshorelines and palaeooceanographic conditions. The importance of mapping is not confined only to reconstructing palaeocoastlines but also extends to reconstructions of the environment, topography and resources that would have been available on the submerged landscape and ultimately to prediction of target areas worth searching for archaeological remains. Many examples are presented in this section, ranging from large-scale mapping of broad areas to more localised investigations. An example of the former is the palaeogeographic mapping of the Aegean Basin (Galanidou et al., Chap. 19, this volume; Figs. 19.2 and 19.3), which shows how dramatically the proportion of land and sea has changed on Pleistocene timescales.

Examples from other chapters refer to regional or more localised investigations involving offshore survey and comprising varying combinations of acoustic survey, diving and coring in marine basins adjacent to concentrations of known archaeological sites on land that can provide a basis for predicting the locations of underwater sites. These include geophysical survey combined with diving and excavation of an underwater cave on the narrow shelf adjacent to the Neanderthal sites of Gorham's Cave and Vanguard Cave in Gibraltar and geophysical survey, landscape reconstruction and diving offshore of northern Spain with its many Palaeolithic cave sequences (Arias, Chap. 13, this volume); geophysical survey, diving and coring in the Bay of Kiladha in southern Greece opposite the Franchthi Cave and geophysical survey and landscape reconstruction in the Inner Ionian Sea and the Kalloni Gulf of Lesbos in the Aegean, offshore of islands with significant Middle Palaeolithic and Lower Palaeolithic finds, respectively (Galanidou et al., Chap. 19, this volume); predictive site location and offshore geophysical survey on the NW Black Sea shelf of the Ukraine offshore of the abundant record of Upper Palaeolithic sites on the adjacent land (Kadurin et al., Chap. 21, this volume); and Cyprus, where the association of stone tools with aeolianite ridges on the modern coast has led to diver survey for similar features underwater.

The most ambitious of these projects is described in the chapter on Ukraine where the chance recovery of flint artefacts in sediment cores from earlier geological research has encouraged a new investigation with archaeological objectives (Kadurin et al., Chap. 21, this volume). The new research involved the analysis of the association between archaeological sites on land and topographic features, geology and raw material resources, an exercise facilitated by the availability of a large sample of Upper Palaeolithic sites on the tributaries of the large rivers that drain into the north-west sector of the Black Sea. The results were then used to identify likely target areas on the submerged shelf, using a 
combination of geological mapping and geophysical survey to assess conditions of preservation and chances of site discovery. Target areas with the appropriate combination of features were further explored, but limitations of funds and equipment prevented further investigation, and identified the need for a programme of sediment coring as an important requirement of future research.

Two of the localised studies summarised above provide instructive examples of successful predictive modelling. Underwater research in Kiladha Bay was carried out in the 1980s as a pioneering exercise in geophysical survey to reconstruct features of the submerged topography, combined with hand coring in shallow water 2-3 km offshore at a depth of c. $5 \mathrm{~m}$. Two cores revealed the presence of Neolithic pottery, charred plant fragments, fish vertebrae and mollusc shells, indicating the presence of a former site on the banks of a palaeo-river. New investigations are under way to build on these early investigations (Gifford 1983; Galanidou et al., Chap. 19, this volume). The work in Cyprus began as a search for early lithic material in support of a preNeolithic occupation, stimulated by an interest in early seafaring (Ammerman, Chap. 22, this volume). The discovery of aeolianite ridges on the coast with surface lithics of Epipalaeolithic type belonging to a period when sea level was significantly lower than present led to a successful search for similar features underwater some $130 \mathrm{~m}$ offshore at a depth of $12 \mathrm{~m}$.

These two examples provide an interesting case of proceeding in small steps from the known archaeology on land to likely targets nearby in shallow water. In both cases, new work is under way or planned to extend this predictive process to the search for earlier sites in deeper water.

\subsection{Underwater Villages}

Although the total number of underwater sites in this region is quite small, the number of submerged settlements (including in situ cultural layers) is relatively large, 76 out of 138 finds $(55 \%)$, with notable concentrations in Bulgaria and Israel (Appendix 1). These underwater settlements are broadly of two types: sites associated with shallow coastal lagoons and anaerobic sediments with timber remains, often discovered by dredging of sediments to keep open channels for sea traffic, and sites with remains of stone structures visible at the shore edge or in shallow water. Examples of the former are Leucate-Corrège on the French Mediterranean (Billard et al., Chap. 12, this volume), Zambratija in Croatia (Radić Rossi et al., Chap. 18, this volume) and an important group of sites on the Black Sea coast of Bulgaria (Peev et al., Chap. 20, this volume). Examples of the latter are partially submerged settlements in Greece of Neolithic or Bronze Age date, notably the site of Pavlopetri (Galanidou et al., Chap. 19) and another important group of Neolithic sites on the Carmel coast of Israel (Galili et al., Chap. 23, this volume).

The Bulgarian sites have been only partially excavated and published, but it is clear that they represent substantial villages of Eneolithic and Early Bronze Age date, c. 6500-4500 cal BP, with extensive wooden structures now submerged at depths down to about $-7 \mathrm{~m}$. These comprise wooden platforms that appear to have been built to provide a dry and stable surface on low-lying ground liable to flooding and remains of dwellings. There are large quantities of ceramics, stone and bone artefacts, animal bones and evidence of subsistence economies that combined cereal cultivation and domestic livestock with hunting of wild animals such as wildfowl, fishing and sea mammal hunting.

The Black Sea has a complex and muchcontested pattern of sea-level change following the LGM because of its isolation from the world ocean, with claims for a dramatic flood that would have drowned large areas of land as global sea-level rise overtopped the Bosphorus sill that separates the Black Sea from the Sea of Marmara and the Mediterranean. The Bulgarian underwater sites are later in date than this postulated flood event and are not related to it, but they provide some insight into the conditions of preservation associated with underwater sites in the region, as well as evidence of ongoing complexities of relative sea-level change at quite a late date, in which 
glacio-hydro-isostatic warping of the Earth's crust is implicated, with the possible addition of a tectonic component. The existing sites offer considerable potential for new research, and new underwater investigations are under way involving excavation and more extensive mapping and coring of the submerged landscape in deeper water.

The sites on the Carmel coast in Israel represent one of the best studied groups of underwater sites in the Mediterranean and Black Sea basins, with investigation and excavation over a long period. As in Bulgaria, these underwater sites appear to fill a gap in the archaeological sequence, indicating the importance of underwater investigations in identifying the missing coastal component of site distributions and settlement patterns in a wider region. The Israeli sites range in age from about 9000 to $6800 \mathrm{cal} \mathrm{BP}$ and in depth from the intertidal zone to $-12 \mathrm{~m}$. They are justly famous for their extraordinary range and quality of evidence, which includes stone structures, pits, courtyards, stone and wood-lined water wells, stone-lined graves, a megalithic ritual structure and a wide variety of well-preserved organic materials including wood, remains of plant foods, basketry and bone. The economy combined fishing, cereal cultivation, domestic livestock and hunting of wild animals, and the settlements attest to a high degree of residential stability founded on this mixed marine-terrestrial subsistence base until rising sea level finally forced their abandonment. The large sample of wellpreserved human skeletons recovered from underwater burials has facilitated insights into demographic patterns and disease.

\subsection{Conclusions}

Despite the large area covered in this section and the somewhat scattered and patchy distribution of underwater sites, the material already discovered includes a considerable range and variety of sites, many with a high quality of preservation, and new research is moving forward in several regions, with indications of the potential for many new discoveries.
At the same time, there are still large gaps in geographical coverage. Turkey remains largely a blank where 'underwater archaeology of prehistoric landscapes is not even at an incipient stage' (Özdoğan 2011, p. 226) and has been much overshadowed by work on shipwrecks. What few finds have been discovered are mostly submerged or partially submerged remains of Neolithic and Bronze Age settlements around the Sea of Marmara in the north-west and are well summarised by Özdoğan (2011) and Öniz (2018). With coastlines facing the eastern Mediterranean, the Aegean and the Black Sea and a variety of coastal and offshore topographies including rocky coastlines with important Palaeolithic coastal cave sequences, such as Yarimburgaz and Okuzini (Yalçinkaya et al. 2002; Clark Howell et al. 2010), the coastal regions of Turkey occupy a key geographical position between the Near East and Europe. There is every reason to suppose that they hide underwater palaeolandscapes and archaeological material comparable to the discoveries in the neighbouring regions of Greece and Bulgaria. Elsewhere, the Adriatic coastline of Italy has scarcely been explored for its underwater potential, and the African shores of the Mediterranean are a complete blank.

The arrangements in place for the management of the underwater cultural heritage are quite variable. Arias (Chap. 13, this volume) draws attention to the bureaucratic complexities of securing permission for offshore survey in Spain requiring the involvement of seven different organisations and governmental agencies with overlapping interests. More generally, arrangements for incorporating the underwater cultural heritage in monitoring offshore industrial work and establishing collaborations with offshore industrial companies appear to be less well developed than in NW Europe, although the potentially destructive pressures of coastal and offshore construction work and commercial activities are every bit as intensive as in other regions, and this is a major concern throughout the Mediterranean and Black Sea basins.

There are, thus, considerable challenges confronting underwater research in this region, as well as growth areas of new and energetic 
research activity, with opportunities for new discoveries and the potential to illuminate in new ways some of the most important themes of human development and the growth of civilisations in a region that plays a key role in the larger picture of world prehistory.

\section{References}

Abelli L, Agosto MV, Casalbore D, Romagnoli C, Bosman A, Antonioli F, Pierdomenico M, Sposato A, Chiocci FL (2016) Marine geological and archaeological evidence of a possible pre-Neolithic site in Pantelleria Island, Central Mediterranean Sea. In: Harff J, Bailey G, Lüth F (eds) Geology and archaeology: submerged landscapes of the continental shelf, vol 411. Geological Society, London, pp 97-110

Angelova H, Draganov V (2003) Underwater archaeological excavations of submerged Late Eneolithic and Early Bronze Age settlements in Kiten and Sozopol (South Bulgarian Black Sea coast). In: Angelova $\mathrm{H}$ (ed) Honorem Mihaili Lazarov. Thracia Pontica 6, vol 2. Centre for Underwater Archaeology, Sofia, pp 9-22

Athanassiou A, Herridge V, Reese D, Iliopoulos G, Roussiakis S, Misopoulou V, Tsiolakis E, Theodorou G (2015) Cranial evidence for the presence of a second endemic elephant species on Cyprus. Quat Int 379:47-57

Bailey G, Carrión JS, Fa DA, Finlayson C, Finlayson G, Rodríguez-Vidal J (eds) (2008) The coastal shelf of the Mediterranean and beyond: corridor and refugium for human populations in the Pleistocene. Quat Sci Rev 27(23-24):2095

Barker G, Hunt C, Reynolds T (2007) The Haua Fteah, Cyrenaica (Northeast Libya): renewed investigations of the cave and its landscape. Libyan Stud 38:93-114

Benjamin J, Bekić L, Komšo D, Koncani Uhač I, Bonsall C (2011) Investigating the submerged prehistory of the eastern Adriatic: progress and prospects. In: Benjamin J, Bonsall C, Pickard C, Fischer A (eds) Submerged prehistory. Oxbow, Oxford, pp 193-206

Benjamin J, Rovere A, Fontana A, Furlani S, Vacchi M, Inglis RH, Galili E, Antonioli F, Sivan D, Miko S, Mourtzas N, Felia I, Meredith-Williams M, Goodman-Tchernov B, Kolaiti E, Anzidei M, Gehrels R (2017) Late Quaternary sea-level changes and early human societies in the central and eastern Mediterranean Basin: an interdisciplinary review. Quat Int 449:29-57

Blanc AC (1940) Industrie musteriane e paleolitiche superiore nelle dune fossile e nelle grotte litorannee del Capo Palinuro. Rendiconti della Reale Academia d'Italia 10, 7(1):602-615

Broodbank C (2014) So... what? Does the paradigm currently want to budge so much? J Mediterr Archaeol 27(2):267-272
Clark Howell F, Arsebuk G, Kuhn SL, Ozbasaran M, Stiner MC (eds) (2010) Culture and biology at a crossroads - the middle Pleistocene record of Yarimburgaz Cave (Thrace, Turkey). Ege Yayinlari

Clarkson C, Jacobs Z, Marwick B, Fullagar R, Wallis L, Smith M, Roberts RG, Hayes E, Lowe K, Carah X et al (2017) Human occupation of northern Australia by 65,000 years ago. Nature 54(7663):306-310. https://doi.org/10.1038/nature22968

Davis SJM (1967) The archaeology of animals. Batsford, London

Dennell RW, Louys J, O’Regan HJ, Wilkinson DM (2014) The origins and persistence of Homo floresiensis on Flores: biogeographical and ecological perspectives. Quat Sci Rev 96:98-107. https://doi.org/10.1016/j. quascirev.2013.06.031

Ferentinos G, Gkioni M, Geraga M, Papatheodorou G (2012) Early seafaring activity in the southern Ionian Islands, Mediterranean Sea. J Archaeol Sci 39:21672176. https://doi.org/10.1016/j.jas.2012.01.032

Flemming N, Antonioli F (2017) Prehistoric archaeology, palaeontology, and climate change indicators from caves submerged by change of sea level. In: Campbell PB (ed) The archaeology of underwater caves. Highfield Press, Southampton, pp 23-38

Galanidou N (2009) Foragers or farmers? Aegean prehistoric research and the beginnings of the Cretan prehistory thread. In: Kopaka K (ed) Aegean prehistoric research in the beginning of the 21 st century. Crete University Press, Herakleio, pp 13-42

Galanidou N (2014) Archaic hominins on Crete: fact or fiction? J Mediterr Archaeol 27(2):260-267

Galanidou N, Sakellariou D, Zavitsanou A, Papoulia C, Rousakis G, Alexopoulos I (n.d.in prep) Neanderthal sea crossings in the Inner Ionian Sea Archipelago: Palaeolithic archaeology and palaeogeographic reconstruction during Late Quaternary low sea-level periods

Galanidou N (2018) Parting the waters: Palaeolithic archaeology in the central Ionian Sea. Journal of Greek Archaeology 3:1-22

Gifford J (1983) Core sampling of a Holocene marine sedimentary sequence and underlying Neolithic cultural material off Franchthi Cave, Greece. In: Masters PM, Flemming NC (eds) Quaternary coastlines and marine archaeology. Academic, London/New York, pp 269-281

Hiscock P (2008) Archaeology of ancient Australia. Routledge, London

McBurney CBM (1967) The Haua Fteah (Cyrenaica) and the Stone Age of the South-East Mediterranean. Cambridge University Press, London

Öniz H (2018) Turkey-Gateway between Asia and Europe. In: Fischer A, Pedersen L (eds) Oceans of archaeology, Jutland Archaeological Society Publications vol 101. Jutland Archaeological Society, Højbjerg, pp 100-107

Papoulia C (2016) Late Pleistocene to early Holocene sea-crossings in the Aegean: direct, indirect and controversial evidence. In: Ghilardi M (ed) Géoarchéologie des Îles de Méditerranée. CNRS Editions, Paris, pp 33-46 
Papoulia C (2017) Seaward dispersals to the NE Mediterranean islands in the Pleistocene. The lithic evidence in retrospect. Quat Int 431:64-87. https://doi. org/10.1016/j.quaint.2016.02.019

Papoulia C (2018) Pleistocene sea-crossings and submerged terrestrial routes. A view from the Inner Ionian Archipelago. PhD Dissertation, University of Crete

Phoca-Cosmetatou N, Rabett RJ (2014) Reflections on Pleistocene island occupation. J Mediterr Archaeol 27(2):255-278

Runnels C (2014) Early Palaeolithic on the Greek Islands? J Mediterr Archaeol 27(2):211-230

Sakellariou D, Galanidou N (2016) Pleistocene submerged landscapes and Palaeolithic archaeology in the tectonically active Aegean region. In: Harff J, Bailey G, Lüth F (eds) Geology and archaeology: submerged landscapes of the continental shelf, vol 411. Geological Society London Special Publications, London, pp 145-178. https://doi. org/10.1144/SP411.9

Sakellariou D, Galanidou N (2017) Aegean Pleistocene landscapes above and below sea-level: Palaeogeographic reconstruction and hominin disper- sals. In: Bailey GN, Harff J, Sakellariou D (eds) Under the sea: archaeology and palaeolandscapes of the continental shelf. Springer, Cham, pp 335-359

Tixier J (1974) Fouille à Ksar'Aqil, Liban (1969-1974). Paléorient 2:187-192

Whallon R (ed) (2018) Crvena Stijena in cultural and ecological context: interdisciplinary research in Montenegro. Montenegrin Academy of Sciences, Podgorica

Yalçinkaya I, Otte M, Kozlowski JK, Bar-Yosef O (2002) La grotte d' Öküzini: Évolution du Paléolithique final du sud-ouest de l'Anatolie. Études et Recherches Archéologiques de l'Université de Liège 96. Liège, Belgium

Laskaris N, Sampson A, Mavridis F, Liritzis I (2011) Late Pleistocene/early Holocene seafaring in the Aegean: new obsidian hydration dates with the SIMS-SS method. J Archaeol Sci 38(9):2475-2479

Özdoğan M (2011) Submerged sites and drowned topographies along the Anatolian coasts: an overview. In: Benjamin J, Bonsall C, Pickard C, Fischer A (eds) Submerged prehistory. Oxbow, Oxford, pp 219-229

Open Access This chapter is licensed under the terms of the Creative Commons Attribution 4.0 International License (http://creativecommons.org/licenses/by/4.0/), which permits use, sharing, adaptation, distribution and reproduction in any medium or format, as long as you give appropriate credit to the original author(s) and the source, provide a link to the Creative Commons licence and indicate if changes were made.

The images or other third party material in this chapter are included in the chapter's Creative Commons licence, unless indicated otherwise in a credit line to the material. If material is not included in the chapter's Creative Commons licence and your intended use is not permitted by statutory regulation or exceeds the permitted use, you will need to obtain permission directly from the copyright holder. 